\title{
EN LOS CONFINES DE RAYYA. ALGUNAS CONSIDERACIONES EN TORNO A ESTEPA Y SU ALFOZ EN ÉPOCA ANDALUSÍ
}

\author{
ON THE BORDERS OF RAYYA. SOME CONSIDERATIONS ON \\ ESTEPA AND ITS TERRITORY DURING AL-ANDALUS TIMES
}

VIRGILIO MARTÍNEZ ENAMORADO Consejería de Educación y Cultura. Junta de Andalucía, Málaga

\begin{abstract}
Resumen: Este trabajo analiza el territorio y la ciudad de Estepa (Sevilla) en época andalusí, atendiendo a la historiografía (árabe y castellana de la conquista), a la arqueología y a la toponimia. Se realiza un recorrido diacrónico sobre el poblamiento de la ciudad andalusí de Istabba y su tierra o alfoz en época medieval, incluido en la küra de Rayya (dependencias de Málaqa o Rayya), desde los inicios del siglo VIII hasta la conquista castellana.
\end{abstract}

Palabras clave: Al-Andalus; Estepa; Istabba; Rayya; historiografía; arqueología.

\begin{abstract}
This paper analyzes the territory and the city of Estepa (Seville, Spain) in the Andalusian period, with reference to the historiography (Arabic and Castilian of the conquest), archaeology and toponymy. The aim of this paper is to examine the territory or fahs of Istabba in the medieval period, included in the küra (province) of Rayya (dependencies of Mālaqa or Rayya), from the beginnings of the 8th century up to the Castilian conquest.
\end{abstract}

Keywords: Al-Andalus; Estepa; Istabba; Rayya; historiography; archaeology.

\section{SUMARIO}

1. Sobre la posible inclusión de Estepa en la cora de Rayya.- 2. Sobre Estepa como distrito campesino. Una primera aproximación a partir de la documentación santiaguista y su "adecuación" arqueológica.- 3. Sobre las referencias a Estepa en la historiografía árabe.- 4. Sobre los límites del alfoz de Estepa. El caso de la mezquita del Cortijo de las Mezquitillas (término municipal de Antequera, Málaga).- 5. Apéndice. Referencias historiográficas de la Estepa andalusí.- 6. Bibliografía citada.

Estepa (hișn/madina Istabba/Istabba/ Isțabba) y su alfoz (hawz) o "tierra" puede representar un ejemplo muy significativo para el estudio de las "periferias de la periferia" de al-Andalus. Como parte integrante de la cora o circunscripción emiral/califal de Rayya (territorios dependientes de Málaga/ Archidona a lo largo del período omeya -emiral y califal-), forma parte de 
uno de tantos territorios o distritos campesinos de al-Andalus necesitados de estudios parciales que ahonden en el conocimiento histórico de ese territorio. De su riqueza como terreno agrícola de gran valor dan cumplida mención los cronistas y geógrafos andalusíes. La toponimia posterior a la conquista, que aporta unos límites muy precisos de esta tierra, puede ayudar a desvelar las dimensiones de ese alfoz y su relación con el centro del distrito, la localidad de Estepa, convertido en uno de los típicos ḥușūn (fortificaciones) andalusíes que asumen funciones proto-urbanas a partir del siglo $\mathrm{X}$ en adelante.

Pretendemos con este trabajo manejar ese triple registro: el exclusivamente arqueológico, el cronístico de las fuentes árabes y, finalmente, el documental castellano que traerá alguna que otra novedad historiográfica. Al mismo tiempo, valoraremos la inclusión de este alfoz estepeño en la cora de Rayya, ateniéndonos a esos registros antes mencionados.

\section{SOBRE LA POSIBLE INCLUSIÓN DE ESTEPA EN LA CORA DE RAYYA}

La situación geográfica de Estepa, en el corazón de Andalucía, entre Sevilla, Córdoba y Málaga, por un lado, y la imprecisión en la que nos movemos a la hora de establecer cabalmente las relaciones administrativas de determinados territorios de al-Andalus, por otro, explican las dificultades que encontramos para fijar la adscripción de Estepa a alguna de las coras limítrofes de su alfoz. Los argumentos de A. Arjona Castro ${ }^{1}$ o de R. Valencia ${ }^{2}$ entran dentro de la lógica: por cercanía, este alfoz pudo integrarse como iqlìm de la cora de Écija, si bien no existe base argumental alguna, salvo la derivada de su cercana ubicación, para certificar esa relación administrativa, que tampoco aprecia J. Vallvé Bermejo ${ }^{3}$. Todo ello fue destacado en la importante contribución de R. G. Peinado Santaella ${ }^{4}$, donde se plantea en sus justos términos esta incógnita historiográfica. Volvemos, sin embargo, sobre los dos textos que aportan información relevante a afectos administrativos.

El primero, que lleva a considerar a varios estudiosos que la inclusión de Estepa en la cora astigitana es un hecho, lo encontramos en una obra tardía (siglo XIV), la Marqaba de al-Bunnāhī, delimitación relativamente precisa -única en su género para las coras andalusíes- de la circunscripción de

1 A. Arjona Castro, Andalucía musulmana, pp. 45 y 58.

2 R. Valencia Rodríguez, Territorios de la cora de Écija, p. 321; R. Valencia Rodríguez, Noticia de la Estepa árabe, p. 188.

3 J. Vallvé Bermejo, División territorial, pp. 331-333.

4 R.G. Peinado Santaella, Estepa en la Edad Media, pp. 151-155. 
Rayya ${ }^{5}$. Aquí volvemos a reproducir este pasaje, centrándonos en la parte que nos interesa, los confines más septentrionales de Rayya:

Al norte [la cora de Rayya] confinaba con el Wādī Šanīl (el río Genil), donde están Hiṣn Banī Bašir (Castillo de Benamejí) y alRanīsūl (Castillo de Anzur). Después seguía la divisoria por la tierra llamada al-Junūs (Alhonoz), hasta la alquería de Ŷilyāna, cerca de Istabba (Estepa), hasta el alfoz de Mawrūr (Morón de la Frontera ${ }^{6}$.

Como puede ser comprobado, en el texto se menciona expresamente Estepa, sin ningún tipo de categoría terminológica, aunque de la alquería (qarya) de Gilena (Yilyāna) se indica que está próxima a nuestra localidad. Esa "subordinación" de Gilena a Estepa expresa, sin duda, distinto rango administrativo, de tal manera que es posible suponer una condición de madina para Estepa. Si aceptamos que este texto debe pertenecer a los años centrales de la décima centuria, tendríamos que Estepa contaba ya con un alfoz, que incluía Gilena, y tal vez con una atribución genérica de madina, otorgada al enclave después de la revuelta de Ibn Ḥafșūn, tras la remodelación acontecida con la instauración del Califato y el fin de la fitna.

$\mathrm{Al}$ no incluir este relato los nombres de las coras contiguas, no se puede establecer la pertenencia de estos lugares a las mismas. Es evidente que tanto Morón como Écija formaban distintas coras, pero, como se pregunta Peinado, ¿en qué lado de la 'línea divisoria' quedaban estos lugares? ¿en el de la jurisdicción malagueña o en el de la no mentada de Écija?7.

Es más, es seguro que la jurisdicción de Estepa alcanzara hasta el río Genil, como la documentación de la Orden de Santiago pone en evidencia. La preposición "hasta" (hattà) del texto de al-Bunnāhī puede significar que Gilena sea la última de las alquerías de Rayya y Estepa la primera en este sector de los territorios dependientes de Écija. ¿Pudiera ser que algún testigo toponímico sea recuerdo de esa delimitación de Rayya, tal vez esa fuente ${ }^{8} \mathrm{o}$

5 Sobre el significado histórico de la cora de Rayya, con numerosas alusiones, V. Martínez Enamorado, Al-Andalus desde la periferia.

6 Al-Bunnāhī, al-Marqaba, p. 82.

7 R.G. Peinado Santaella, Estepa en la Edad Media, p. 151.

8 "Y porque otra veçes por el provecho que dello viene para los pastores de los ganados, y entradas y salidas a las fuentes de Gilena, y Roya, y el Moralejo"; R. Garza Cortés, Villa de Estepa, p. 88; "Otrosy, hordenaron y mandaron que de aquí adelante ninguna persona no de agua a los puercos en la Corachuela, ni en el pilarejo, ni en los pozos dulces, ni en las pilas de Roya, ni en el alberca questá en Roya", ibidem, p. 98; "e por ençima de la fuente de Arroya hasta dar en la sierra que está junto a la villa de Estepa", ibidem, $p$. 142-143; "Pues, en la dicha villa, sepa Vuestra Majestad que tiene una fuente de que beben que llaman Arroya, que está de la dicha 
alcoba (de $a l-q u b b a)^{9}$ de Roya muy próxima a Estepa, topónimo y depósito que aún se conservan?

Finalmente, cabría hacerse una pregunta para la que tampoco tenemos por ahora respuesta: ¿podría ser el territorio de Estepa una cora autónoma de acuerdo con algún testimonio que así lo consigna ${ }^{10}$ ? De lo contrario, ¿se podría explicar esta circunstancia con los mismos argumentos que se utilizaron para el caso de Osuna, nombrada como cora en una sola ocasión (Muqtabis $\mathrm{V}^{11}$ ) en el año 923, algo meramente coyuntural que obedecía las condiciones políticas de la zona al final del emirato y principios del califato ${ }^{12}$ ? ¿O ni siquiera eso y se trata de una mera licencia literaria sin traslación posible al campo de lo administrativo? Conviene recordar que la cita de la kūrat Istabba de Ibn Sa'īd, recogida en la recopilación de al-Maqqarī y no en su al-Mugrib fi hulà al-magrib, se inserta en una relación de varias localidades a las que todas se le aplica la misma terminología de kūra. Parece en este contexto -es verdad- un recurso literario de difícil concreción histórico-administrativa, lo que no significa, en cualquier caso, que esa realidad no existiera.

El segundo de los testimonios se incluye en la breve descripción de

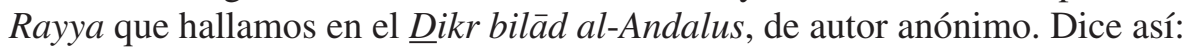

La ciudad de Rayya está al sur de Córdoba y tiene jurisdicción sobre numerosas ciudades y castillos inaccesibles (...) Entre sus castillos y ciudades se cuentan Marbella, Fuengirola, Cártama, Comares, Vélez-Málaga, Coín, Alhama, Antequera y Estepa; todos ellos son castillos inaccesibles que producen grandes cantidades de higos, aceitunas, almendras, uvas y granadas ${ }^{13}$.

No creo que a este testimonio se le pueda restar fiabilidad porque de las nueve localidades citadas ocho pertenecen con toda seguridad a la cora de Rayya, siendo significativo que no se incluya Ronda por ser entonces parte de la cora de Tākurunnā. La secuencia en la presentación de los topónimos se inicia en el occidente (Marbella), para continuar hacia el Este por la costa (Fuen-

villa, a nuestro parecer, tanto de Valladolid a la fuente de Argales (...) Y, sólo esta (la fuente del Peralejo) y la de Arroya tienen hordinariamente (agua) para beber", ibidem, pp. 164-165.

9 "Otrosy, ordenaron y mandaron que de oy en adelante ninguna persona, ombre ni mujer, ni muchacha, no lave trapos en el alcoba de Roya", R. Garza Cortés, Villa de Estepa, p. 98. Sobre el topónimo Alcoba y variantes en la toponimia hispánica, $\mathrm{M}^{\mathrm{a}}$.D. Oliver Pérez, El arabismo Alcoba.

10 Al-Maqqarī, Nafh I, p. 456. R. Valencia Rodríguez, Noticia de la Estepa árabe, p. 188, nota 12 lo niega con razones que no podemos sino compartir: "La cita de Estepa como cora que aparece en un autor creemos debe tomarse como referencia geográfica".

11 Ibn Ḥayyān, al-Muqtabis V, 1979, pp. 180-181; trad. castellana p. 141.

12 R. Valencia Rodríguez, Territorios de la cora de Écija, p. 326.

13 Dikr p. 68; trad. castellana, p. 74. 
girola), introducirse en la Algarbía (Cártama), englobar la Axarquía (Comares y Vélez-Málaga), volver al Valle del Guadalhorce (Coín) y finalmente recoger dos alfoces bien delimitados, uno al Este, al norte de la Axarquía y separado de esta comarca, y otro al norte, Antequera. En esta serie, el caso de Estepa es manifiestamente singular por ser el único de estos hușūn que puede plantear alguna problemática en tanto a una adscripción dudosa a Rayya ${ }^{14}$. No descartamos, incluso, que esta inclusión de Estepa sea debida a una extrapolación del copista y que la localidad a la que se alude sea la fortaleza de Teba (Ițâba/ $A t ̦ i ̄ b a)^{15}$, cercana por lo demás a Estepa. En cualquier caso, como en su momento defendimos ${ }^{16}$, seguimos pensando que Estepa formaba parte de Rayya en el período emiral y califal.

\section{SOBRE ESTEPA COMO DISTRITO CAMPESINO. UNA PRIMERA APROXIMACIÓN A PARTIR DE LA DOCUMENTACIÓN SANTIAGUISTA Y SU “ADECUACIÓN” ARQUEOLÓGICA}

El asunto historiográfico, así planteado, no deja de ser de una importancia relativa en comparación con otro, de mayor significación, que a modo de pregunta lo enuncia con claridad Peinado Santaella: Estepa, ¿castillo o 'distrito castral'? ?17.

Y, puestos a elegir, descartaríamos una y otra opción porque, en realidad, la pregunta habría de ser, “¿Estepa, 'distrito castral' o 'distrito campesino'?”, de acuerdo con los postulados que de una manera más o menos franca y abierta están defendiendo distintas posturas historiográficas. ${ }^{18}$

En efecto, el Hisn de Estepa actuaría como cabecera administrativa de un conjunto de unidades agrarias, sujetas a algún tipo de vinculación con ese núcleo que daba nombre al distrito. hiṣn es, en este caso, sinónimo

14 R.G. Peinado Santaella, Estepa en la Edad Media, p. 152 dice que "la adscripción de Estepa -como este pasaje afirma de manera concluyente- a la cora de Rayya no es nada descabellada, y más si se tiene en cuenta que la capital de esa provincia, durante el período omeya, fue Archidona (Aršiduna/Aryiduna), y que sólo tardíamente (¿después de la caída del califato?) la capitalidad pasó a Málaga". Por otro lado, hemos podido comprobar que esa asunción de nuevo de la capitalidad de Rayya por parte de la ciudad de Málaga se produjo en el último tercio

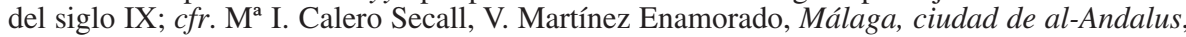
pp. 21-23; V. Martínez Enamorado, Al-Andalus desde la periferia, pp. 341-385.

15 Incluida, sin embargo, en Tākurunnāa; véase V. Martínez Enamorado, Al-Andalus desde la periferia, p. 412.

16 V. Martínez Enamorado, Al-Andalus desde la periferia, p. 411.

17 R.G. Peinado Santaella, Estepa en la Edad Media, p. 155.

18 Nuestro planteamiento lo hemos dejado claro en V. Martínez Enamorado, Reflexiones sobre el estudio de al-Andalus. 
de distrito o iqlìm. Pero si alcanzamos a vislumbrar su significado concreto, tendríamos que se trata de un sistema de asentamientos campesinos (qurà, pl. de alquería) regidos por un centro, un "castillo" (hișn), por más que desconozcamos las dimensiones del mismo en el período de fundación, su fecha de construcción y ni siquiera si estaba edificado en el siglo IX. Mucho nos tememos que en numerosas ocasiones, sobre todo en los años de la revuelta de Ibn Hafṣun, hiș̣n signifique simplemente "lugar alto", ni siquiera fortificado, sino fácilmente defendible, ocupado tal vez de manera ocasional ya sea por comunidades campesinas, ya sea por grupos que podrían ejercer sobre aquellas algún tipo de coerción, ya por agentes del Estado. Después analizaremos lo que de Estepa sabemos en ese período emiral y cuales pudieron ser los protagonistas de esa ocupación de la fortaleza (¿la primera?), a partir de las parcas referencias historiográficas.

Todo este relato tiene una correspondencia que podía ser calificada de empírica en las escasas evidencias arqueológicas que se refieren a Estepa. En un trabajo de prospección arqueológica publicado hace años se establecen unas pautas para los asentamientos andalusíes muy precisas: suelen ser pequeños, cercanos a la población y en zonas de aguas abundantes, superponiéndose en general a poblamientos más antiguos ${ }^{19}$.

Son "impresiones" de carácter general que se corroboran a su vez en otros trabajos que se refieren a la comarca de Écija ${ }^{20}$ y que parecen responder a similitudes en el proceso de ocupación del territorio. La renuncia a las zonas altas y la preferencia por las áreas mejor irrigadas que algunos de los arqueólogos que han trabajado en esta zona detectan revelan que los procesos de "encastillamiento", de existir en al-Andalus, obedecen a lógicas de enorme complejidad interna ("local", cabría decir) y que esa complejidad no puede ser resuelta a base de propuestas que simplifiquen en exceso los fenómenos micro-territoriales o comarcales. Dicho de otra manera, sólo desde lo local se podrán construir hipótesis de carácter más general y, por lo que se comprueba en la comarca de Estepa, ese poblamiento campesino no difiere de otras regiones del sur o del Oriente de al-Andalus, estudiadas con mayor profundidad. Ello significa que se aprovecharon los valles mejor irrigados (Arroyo de la Ribera) y que todos los establecimientos de la Tierra de Estepa del tipo alquería (Pedrera, Gilena...) se emplazan en manantiales, aplicándose criterios de sostenibilidad ecológica y demográfica,

19 J.Ma Juárez Martín, Prospección arqueológica superficial.

20 J.M. Vargas Jiménez, A.S. Romo Salas, M.I. García Ramírez, Aproximación a los modelos de asentamiento: "un factor casi primordial para el establecimiento musulmán es la posibilidad de explotación agrícola frente a otras ventajas que puede ofrecer el medio"; se entiende que esas "otras ventajas" son la altura para la defensa en caso de situaciones bélicas comprometidas. 
que permiten una planificación inicial de las áreas mal llamadas "incultas" (el "monte" de los documentos castellanos). Estas áreas se intervienen, sin embargo, bajo otros criterios y mecanismos, aunque como complemento de esa agricultura irrigada. La abundante documentación castellana muestra la relevancia de esos terrenos "incultos" -desaprovechados en una lógica plenamente economicista del presente- y administrados en una lógica que llamaríamos comunitaria.

Y de ahí pasamos a las dimensiones, algo del todo lógico si de arqueología hablamos. Lo que se plantea en la exposición de Juárez, suelen ser pequeños, tiene que ver con lo dicho por nosotros inmediatamente antes. Aunque estemos lejos de poder dar dimensiones ponderables y precisas de esos asentamientos campesinos de época andalusí en el alfoz de Estepa, lo que deviene del análisis de la prospección detallada de este término municipal realizada por Juárez arroja datos precisos en esa dirección. Estas alquerías, unidades residenciales básicas de poblamiento y de producción ${ }^{21}$, desperdigadas por el territorio y organizadas bajo criterios clánicos, forzosamente hubieron de ser de reducidas dimensiones. En la zona que nos ocupa, esto es la Campiña al Este de Sevilla y del sur de Córdoba, debió existir un poblamiento beréber más intenso de lo que ha sido percibido por la historiografía. Fundamentalmente son grupos clánicos Nafza los que están presentes en esta zona. Todavía en el siglo X la adscripción a los $\mathrm{Nafza}^{22}$ era reivindicada por algunos miembros de la comunidad a tenor de la nisba que acompañaba a unos de los pocos estepeños andalusíes conocidos, 'Alī al-Nafzīi; también Abū Ishāa Ibrāhīm ibn 'Alī ibn Ibrāhīm ibn Muḥammad ibn 'Abd Allāh ibn Aglab alJawlānī al-Zawwālī, de la gente de Estepa -min ahl Istabba-, quien portaba en el siglo XIII dos nisba-s clánicas: Jawlānī y Zawwālī, la primera árabe y la segunda beréber. Los asentamientos de los banū Layt en Setefilla, de los banū Ŷahwar en Marchena o de los maṣmūdíes banū Ṭarīf en Osuna, que en las fuentes árabes apenas si tienen una resonancia reducida, responden a un tipo de ocupación del territorio similar a la que representa la cercana circunscripción de Tākurunnā.

En definitiva, se define al sur del valle del Guadalquivir un territorio ocupado desde el siglo VIII por grupos campesinos beréberes, en el sentido en que se expresaba Guichard: el antepaís de las montañas de Andalucía occidenta $^{23}$. Todo ello parece contradictorio con la percepción de un valle del

${ }^{21}$ Una integral visión de las alquerías emplazadas más al Oeste, en las dependencias de la Sevilla 'abbādí, en A. Tahiri, Agricultura y poblamiento rural.

22 Véanse las referencias a los Nafza de la vecina Tākurunnā en V. Martínez Enamorado, Al-Andalus desde la periferia, pp. 182, 387, 455, 459, 460, 463, 467, 479, 480 у 490.

23 P. Guichard, Al-Andalus, p. 367. 
Guadalquivir ocupado casi en exclusividad por grupos árabes, en la órbita de Córdoba como lugar central, cuando algunos testimonios son sumamente explícitos en el sentido que apuntamos: de 'Ayšūn ibn Isḥāq ibn 'Ayšūn al-Sumāṭī, fallecido en 353, dice Ibn al-Faradị que residía en el campo en el seno de una tribu entre las tribus beréberes (bādiyati-ha wast qabīla min qabā'il albarbar $)^{24}$, lo que dibuja a la perfección, en tan pocas palabras, lo que hubo de ser el poblamiento hasta los siglos XI y XII de los distintos alfoces al sur del valle del Guadalquivir. Así se comprueba para Écija, pero también -estamos seguros- para Estepa o Marchena, entre otras "tierras" de esta amplia región. Nada sabemos de la instalación de ŷundíes en esta región, pero habida cuenta de que se, literalmente, desparramaron por las alquerías de Rayya (distritos de Cártama, pero también Antequera y Archidona ${ }^{25}$ ) es lógico considerar que algunos de estos enclaves sean originados por la instalación de estos contingentes. Si se comprobara esto, y habida cuenta de la certeza de una presencia de esos grupos nafzíes que tímidamente comparecen en las fuentes, tendríamos un poblamiento nuevo y rupturista, muy alejado de la continuidad con los tiempos anteriores que algunos pretenden, queriendo ver incluso unos medios rurales andaluces en los que posiblemente todavía tenían vigor las normas sociales vigentes en la época visigoda ${ }^{26}$.

Pues bien, es curiosamente esa documentación castellana la que va a dar dimensiones, lamentablemente imprecisas para el período que nos ocupa -el andalusí-habida cuenta de su cronología tardía, de la presencia del regadío, el secano y el monte en el término de Estepa. En la pormenorizada visita de $1554^{27}$, observamos:

1. Las tierras de regadío, en buena medida vinculadas a algunas entidades de población anteriores (a alquerías andalusíes), representan tan sólo 57'70 ha y son descritas gráficamente como auténticas "yslas"28 en un "mar" de secano; suelen emplazarse en los alrededores del río Genil.

2. La "sembradura" de cereales se elevaba a la descomunal cantidad de 1.245.455 has, aunque sean tierras en disposición de ser cultivadas para el cereal y

24 Ibn al-Faradị̄, Ta'rīj 'ulamā' I, p. 381, no 997.

25 Sobre ello, con distintas referencias, V. Martínez Enamorado, Al-Andalus desde la periferia, índices.

26 La cita es de M. Acién Almansa, Formación y destrucción, 1984, p. 36 y aparece recogida por R.G. Peinado Santaella, Estepa en la Edad Media, p. 156, nota 156.

27 Todo ello magníficamente analizado por R. Garza Cortés, Villa de Estepa, pp. 11-35.

28 Ibidem: "Ysla de Amor", p. 155; "Ysla de Francisco Torres", p. 155; "Ysla de la Parra", p. 136; "Ysla de la Dehesa de Alonso", p. 155; "Ysla del Ravanal", p. 155; "Ysla del Vado de la Toça"/Badolatosa, p. 154; "Ysla de las Mestas", p. 135; "Ysla del Cañaveral", p. 154; "Ysla de Boca", p. 154; "Ysla de Mençi Alonso", p. 154; "Ysla de Sotogordo", p. 154. 
no puestas en cultivo en ese momento ${ }^{29}$, mientras que los "majuelos" sólo suponían 439 has, viñas que se combinan con el olivar, uno y otro cultivo en abierto ascenso.

3. "Sierras" y "montes", por un lado, y "dehesas" para el ganado, por otro, representan la nada despreciable cantidad de 6.222,11 y 2882,70 has, respectivamente ${ }^{30}$, aunque estos valores, según lo explicado anteriormente en relación con las tierras de sembradura, debían ser ciertamente muy superiores.

No hace falta insistir en la evidencia de que estas cifras no son extrapolables al fahs Istabba, ni siquiera al inmediatamente anterior a la conquista castellana, pero se pueden destacar algunos datos de interés singular que servirán para dibujar con unos trazos aún difusos las dimensiones agrarias de ese territorio campesino que era el alfoz de Estepa ${ }^{31}$. La insignificancia del regadío, auténticos espacios discontinuos e intercalares en las proximidades de surgimientos de aguas, que en los documentos manejados se les llama hojos/ojos del agua ${ }^{32}$, segura traducción del árabe "uyūn (plural de "ayn = "ojo" y, por extensión "fuente"), nos está hablando de un viejo sistema en franco retroceso en comparación con el secano, por más que los visitadores traten de incentivar su ampliación. A los ojos de estos colonizadores, "monte" y "sembradura" son, por lo que se comprueba, incompatibles y el espectacular crecimiento de la segunda se realiza en detrimento del primero. $Y$ aunque las cifras de la "sembradura" son elevadísimas, la presión sobre el "monte" se incrementa, pues son muchas las "tierras por romper", susceptibles de ser convertidas en "tierras de pan". No en vano el proceso roturador de los considerados "bienes comunales" es definido como rápido y devastador ${ }^{33}$. La explicación

29 'La valoración prudente que cabe hacer de la indicación 'para sembradura'. Pues ella alude más a una realidad de futuro que al presente, ya que por su objetivo intrínseco de evaluar el porvenir -la actualidad quedó contemplada y tasada por el valor de las rentas-, en la Visita no se contemplaron los pagos ya efectivamente cultivados, sino aquellos que podían serlo, siendo por eso por lo que todas las superficies así catalogadas eran calificadas también como de 'monte"”; R. Garza Cortés, Villa de Estepa, pp. 30-31.

30 En total, 9.094'81 ha; entendemos que las dos, "sierras" y “dehesas", se ajustan al concepto genérico de "monte".

31 Un botón de muestra de lo que supone la nueva estructura de la propiedad de los castellanos lo tenemos en el caso de J. Jiménez Cavallero; J.M. Mendoza Garrido, Notas sobre la propiedad de la tierra en Estepa.

32 "Ansy mesmo, en honze días del mes de otubre, se bio desde la dicha dehesa de la Roda y la dehesa de Gilena, van començando desde el Hojo del Toro que dizen, y yendo por el camino Real de Málaga que va a Estepa, hasta dar en la Sierra de Algaydilla, e llegar a Peña Ruvia, volver por el camino que ba de Estepa a Alameda", R. Garza Cortés, Villa de Estepa, p. 130; "Fueron primeramente al Hojo del Agua, a unas casas que dizen Gilena la Alta", Ibidem, p. 125; "Ojo de Gilena, la qual ay quinze molinos y se riega dellas a las huertas; donde dizen Aguaduçe, que está legua y media de la dicha villa, y esta agua es una fuente que sale del cortijo de Gilena la Alta; ay otro ojo de agua, a do dizen Sierra las Yeguas, que llaman el ojo del Toro, y ansy mismo en la dicha agua ay molinos y va esta agua a dar al río Genil", Ibidem, p. 164.

33 L. Navarro de la Torre, Algunos apuntes, p. 203. 
se sitúa obviamente en el espectacular incremento demográfico vivido en el término de Estepa, de tal manera que en los cifras de los primeros años de la segunda mitad del siglo XVI habían casi triplicado las de $1534^{34}$.

De ello, se puede inferir que el paisaje andalusí era muy distinto al que imponen los castellanos tras la conquista. Sin duda, el hecho fronterizo supuso un período de incertidumbre que impidió la puesta en marcha de una economía más pujante ${ }^{35}$. El fin de la Guerra de Granada -incluso antes de las principales ciudades, con la toma de Antequera (1410)- provocó con relativa rapidez la imposición de un modelo de intervención en el paisaje mucho más agresivo, con el reemplazo del bosque y la dehesa por los cultivos del olivo, la vid y, sobre todo, el cereal (trigo y cebada). El "monte" debía ser en época andalusí absolutamente preponderante y las dimensiones del secano muy inferiores a las precisadas en el siglo XVI, lo que, es evidente, se ajusta a esas imagen de perímetros irrigados pequeños rodeados mayoritariamente de "monte", vocablo, como señala Peinado, cuyo significado hay que entender en sentido biogeográfico y no topográfico ${ }^{36}$.

Existe otra evidencia historiográfica de gran valor que ayuda a entender el contexto ecológico de Estepa y su alfoz en el siglo XIII y en fechas anteriores: en el Libro de la Montería de Alfonso XI se localizan siete "montes" en la tierra de Estepa, abundantes en "puercos" e incluso, en un caso, en $\operatorname{osos}^{37}$; pues bien, tres de estos cazaderos los encontramos convertidos, dos centurias más tarde (según la visita de 1554), en núcleos poblados: son los viejos cortijos de la Sierra de Yeguas, Corcoya y el Gallo.

Por lo demás, esa documentación de la Orden dibuja con cierta precisión el alfoz de Estepa, estableciendo las dimensiones del mismo y sus límites. Como hemos podido comprobar, sirve para reconstruir el paisaje rural anterior a la conquista; ese paisaje sólo podrá ser transformado a partir del fin de la Guerra de Granada, cuando Estepa deja de ser plaza fronteriza de la "Banda morisca"; a lo largo de dos siglos ese paisaje quedó fosilizado.

No es abundante en toponimia árabe, lo que puede explicarse por el prolongado lapso de tiempo entre la conquista castellana y la documentación de la Encomienda. En efecto, apenas unos cuantos nombres de lugar de pagos menores como sierra de Algaydilla ${ }^{38}$ (diminutivo castellano de $\hat{y}$ abal al-

34 R.G. Peinado Santaella, Estepa en la Edad Media, p. 175; R. Garza Cortés, Villa de Estepa, pp. 16-17.

35 Una brillante exposición en R.G. Peinado Santaella, Estepa en la Edad Media, pp. 160-173.

36 Ibidem, p. 171.

37 Alfonso XI, Libro de la Montería, pp. 662-663; A. López Ontiveros, B. Valle Buenestado, F.R. García Verdugo, Caza y paisaje.

38 "Ansy mesmo, en honze días del mes de otubre, se bio desde la dicha dehesa de la Roda y la dehesa de Gilena, van començando desde el Hojo del Toro que dizen, y yendo por el camino Real de Málaga que va a Estepa, hasta dar en la Sierra de Algaydilla, e llegar a Peña 
Gayda = "bosque", con diminutivo en castellano), la "cañada de los Ginetes" 39 (Zanāta, grupo tribal beréber) o cerro de Calatrava ${ }^{40}$ (kudyat Qal'at Rabāh), existiendo dudas con respecto a otros topónimos, como Arroyo Gaén ${ }^{41}$, tentados a considerarlo un Wād $\bar{\imath}$ Yayyān, como su homónima ciudad andaluza.

Algunos de los topónimos pueden ser reconstruidos en árabe desde la denominación castellana: v.g, Laguna Salada ${ }^{42}=$ Laguna de Fuente de Piedra, debió de ser una Buhayra al-Mallāha, dato que concuerda con la existencia de salinas desde época romana en sus riberas, o el arroyo Vermejo/Bermejo ${ }^{43}$, un Wādì l-Ahmar, tan abundantes en la hidronimia de alAndalus ${ }^{44}$.

Para otros, de claro origen romance, se puede establecer su secuencia evolutiva, presentando en el siglo XIII formas muy estables: así sucede con Casariche, Gilena o Pedrera.

Ruvia, volver por el camino que ba de Estepa a Alameda"; "e comienza la dicha sierra desde el camino que ba de Estepa a Gilena la Alta a la mano yzquierda, e entra elne/sta sierra la sierra de los Cabrones, que es asomando a Alamedilla, e toda la sierra de las Algaydillas hasta la punta de Peña Ruvia, que es hasta el camino que va de Estepa a Antequera que va por la Venta del Alcaide", R. Garza Cortés, Villa de Estepa, pp. 130 y 145, respectivamente.

39 "Ansy mesmo, este dicho día, syguiendo todavía la vía de poniente, e alindando con la dicha vereda que va de las Mestas a Casariche por la cañada de los Ginetes"; "Ansy mesmo, este dicxho día, siguiendo la dicha vesyta, yendo la ribera del dicho río abaxo a las tierras que dizen de Alonso Muñoz e a las tierras de los Pabones que descabezan en la cañada de los Ginetes, dixo que ay en todo de esto tierra monte"; R. Garza Cortés, Villa de Estepa, p. 136.

40 "y entiéndese que se señale que no corten madera ni leña, ni hagan carbón ni çeniza desde Enzina Calatrava, ques mojón de Osuna y Teva y Estepa, hasta el cortijo la Roda"; R. Garza Cortés, Villa de Estepa, p. 83; "E luego, otro día siguiente, diez días del dicho mes de otubre, prosiguiendo en la dicha vesyta, salieron del dcho lugar de la syerra las Yeguas, e volviendo hazia la dicha fuente Amarguilla, e çerro de Calatrava, por donde ba el padrón e mojón entre el término de Estepa y Osuna; e el dicho mojón del çerro de Calatrava parte tres términos, los suso dichos y el término de Teva", Ibidem, pp. 126-127. Sin embargo, puede tratarse de un asentamiento de los calatravos.

41 "Este dicho día, saliendo del dicho cortixo del Alameda, continuando la dicha vesyta, yendo por el camino que va al arroyo Gaén hacia Levante", R. Garza Cortés, Villa de Estepa, p. 132; "e lindando con la dehesa del Alameda, e volviendo al dicho arroyo Vermejo, que está dicho donde entra el arroyo Gaén", Ibidem, p. 134; "hasta el Campillo, de la otra parte del Alameda hasta el arroyo Gaén, que parte término el dicho arroyo entre Estepa e Benamexí e Antequera, ay çinco leguas ", Ibidem, p. 153.

42 "Qualquier persona que cavare o llevare barro del camino de Écija, o del camino de la Salada"; R. Garza Cortés, Villa de Estepa, p. 111; "Ansy mesmo, este dicho día, yendo desde la dicha mezquitilla a la dicha vía de levante, siguiendo la mojonera antigua entre la villa e cibdad de Antequera e por la punta de la laguna Salada, que está çerca de las Alvinas, e continuando todavía la derechera hasta llegar a la syerra de Santeyllán"; Ibidem, p. 128. Otras referencias a la Laguna Salada en el Repartimiento de Antequera, ed. de F. Alijo Hidalgo, Antequera y su Tierra, Málaga, 1983, ff., 96v, 100v, 106r, 137r, 147r, 189v, 190r y 238r.

43 "e lindando con la dehesa del Alameda, e volviendo al dicho arroyo Vermejo, que está dicho donde entra el arroyo Gaén"; R. Garza Cortés, Villa de Estepa, p. 134.

44 E. Terés Sádaba, Materiales, pp. 188-189 y 373-378. 
- Casariche, claramente romance, hubo de tener una forma árabe de Qasāriš o tal vez Qasārî̀, de donde proceden topónimos como el de Casares, al sur de la Serranía de Ronda, en la actual provincia de Málaga; en su proceso evolutivo, Casariche gana una /e/ final de apoyo. Por tanto, la evolución sería: *Qasāriš > * Casarich > Casariche.

- Para Gilena, contamos con una única grafía árabe: Ŷilyān $n^{45}$, a no ser que se contabilice como propia de esta localidad la descripción que hace Yāqūt de una fortificación llamada Ŷilyāna, incluyéndola en las dependencias de Guadix ${ }^{46}$. Es caso bien conocido en el conjunto de antiguos topónimos latinos con el sufijo $/$-ana $/{ }^{47}$. La forma se fija sin apenas variaciones en el siglo $\mathrm{XIII}^{48}$. Quien mejor que Pabón para explicar el topónimo. Esto es lo que decía, apoyado en valiosa bibliografía:

Gilena (Sevilla): Derivado probablemente como Guillena, v. infra, de un nombre germánico: podría aducirse Gilo (...), pero por razón de frecuencia en España acaso sea más aconsejable hacerlo de Agila o Egila., contando con la aféresis: cf. Topónimos derivados muy abundantes en Förstemann, II, 1, 25. Meyer-Lübke cree que Egila es irreductible a Agila.. No hay que recordar la serie de nombres propios derivados de Gails (pica), Meyer-Lübke, 29, Sobre el tratamiento de la G-inicial, G. Sachs, Die german Ortsnam in Spanien und Portugal, 19.

Giliena: Rep. De Sevilla (G.). Sin duda la Chilyena mencionada supra. Podía derivarse de Agilius. (Schulze, 440) con aféresis.

- En los primeros testimonios de la documentación de la encomienda de Santiago, Pedrera ya aparece con esa forma derivada de una primigenia Petra + aria, con la ulterior sonorización de la /t/ en /d/, el desplazamiento de la /i/ a la sílaba anterior y la monoptongación del diptongo /-ay-/ en /e/. La secuencia sería *Petra+aria $>*$ Petraira $>*$ Pedraira $>$ Pedrera. El resultado final es un topónimo con un innegable aspecto castellano, evolucionado desde

45 Al-Bunnāhī, Marqaba, p. 82; señala E. Lévi-Provençal que la grafía que ofrece uno de los manuscritos es Ŷayyān, la misma que Jaén, mientras que en otro aparece Ŷiliyāan; por el contrario, en la edición de Maryām Qāsim Tawīl, p. 110, se incluye la forma que entendemos es correcta: Ŷraliyāna.

46 Yāqūt al-Hamawī, Mu' $\hat{y}$ am al-buldān, II, p. 109; trad. española de los textos referentes a al-Andalus de Gamal 'Abd al-Karìm, La España musulmana en la obra de Yāqūt, p. 152, núm. 128: "Ŷilyāna. Es un castillo (hiṣn) en al-Andalus, dependiente de Guadix (min a 'māl Wādī Āš). Está muy fortificado y abundan en él las frutas. Se le llama Ŷilyāna al-tufāha por cultivarse allí las mejores manzanas y por su buen olor; se dice que al comerlas se encuentra en ellas el sabor del azúcar y del almizcle". A continuación aporta la biografía de un personaje de allí procedente, 'Abd al-Mu'min ibn 'Umar ibn Hasan, poeta y médico del siglo XII.

47 J.M. Pabón, Sobre los nombres, pp. 105-106.

48 Todavía en el siglo XVIII, se empleaban indistintamente las formas Gilena y Jilena; por ejemplo, J.O. Prieto Pérez, El Marquesado de Estepa, p. 185. 
conocidas formas romances, de las que en otros lugares de al-Andalus se tiene constancia ${ }^{49}$, como Petrer, Petrayr o Petrayra. Queda, con todo, la duda de que sea un topónimo beréber, como defiende Barceló ${ }^{50}$ para explicar la etimología de Bitra/Bytra de Mallorca

\section{SOBRE LAS REFERENCIAS A ESTEPA EN LA HISTORIOGRAFÍA ÁRABE}

Por supuesto, nada de lo anteriormente expuesto se vislumbra siquiera en la escasa documentación árabe. No obstante, las diversas noticias historiográficas relativas a Estepa, anteriormente interpretadas con solvencia por R. G. Peinado Santaella ${ }^{51}$, R. Valencia ${ }^{52}$ o J. $M^{\mathrm{a}} \mathrm{Juárez}^{53}$, nos están hablando en exclusividad de una localidad, ya sea "castillo", ya "ciudad", ya ambas cosas a la vez, otra tantas de las que salpicaban el territorio andalusí. No obstante, se aprecia una cierta evolución en la terminología sobre la que tendremos ocasión de incidir.

Sin duda, es de gran valor porque introduce a Estepa en la historia y en la historiografía de al-Andalus el pasaje del Muqtabis III de Ibn Hayyān. Se refiere a la expedición que en el verano de 276/889 realizó el emir 'Abd Allāh contra Ibn Ḥafṣun. Este es el episodio contado por el gran cronista cordobés:

Salió el maldito 'Umar ibn Hafșūn con su ejército y pertrechos hacia la región de Écija (nāhiya Istî̀̂ya), uniéndose a él la distinta gente de la disidencia (ah̉l al-jilāaf). Se alió con 'Awsaŷa de la gente $(a h l)$ de los Jalī‘ al-Tākurunnì y pactó con él. Y con todos los que con él estaban de la gente de Tākurunnā (ahl Tākurunnāa). Se presentó en la fortaleza de Estepa (hișn Iștabba), haciendo salir de la misma al gobernador del sultán ('ämil ăl-sultāan) y se apoderó de ella. Y después pasó a la fortaleza de Osuna (hiṣn Ušunna $)^{54}$

El testimonio es sumamente claro: en Estepa, estaba implantado un representante del sultán ('âmil al-sulțān), un delegado del poder central que tal vez ejerciera algún tipo de control fiscal sobre este alfoz. Desalojado por Ibn Ḥafṣūn, el enclave pasó a estar controlado por el rebelde de Bobastro. La

49 Una grafía originaria andalusí próxima a nuestro caso sería Bitrīr enYāqūt al-Ḥamawī, $M u$ 'ŷam al-buldān, I, p. 489 y trad. p. $108, \mathrm{n}^{\circ} 65$.

50 M. Barceló, Notes berbers $i$ saharianes, pp. 136-138.

51 R.G. Peinado Santaella, Estepa en la Edad Media.

52 R. Valencia Rodríguez, Noticia de la Estepa árabe.

53 J.M Juárez Martín, Prospección arqueológica superficial.

54 Ibn Hayyān, al-Muqtabis III, p. 54. El episodio aparece mencionado también por Ibn al- Jatịib, A'māal al-a'lām, p. 28. 
mera inclusión de esta construcción sintáctica es reveladora del desenvolvimiento de unas actividades cercanas al poder omeya en la fortaleza de Estepa en el siglo IX, por más que sólo podamos afinar parcamente cuales eran esas funciones del 'àmil al-sulțān ${ }^{55}$. Bien es cierto que su aparición en las crónicas árabo-andalusíes se relaciona con grandes unidades territoriales, coras, y no con pequeños distritos o fortificaciones, como se presupone para el caso de Estepa.

Ibn al-Qūtiyya, por su parte, nos proporciona una noticia muy interesante sobre Estepa que a la luz de la documentación castellana puede ser reinterpretada. En la descripción de la actividad de Ibn Abī 'Abda, se dice que,

Los espías que habían apostado para dar cuenta de los movimientos de Ibn Abī 'Abda se le presentaron a Ibn Ḥafsūn y le hicieron saber que aquel había pasado el río Genil (Wädī Šanìl) y estaba en los alfoces de Peña y Estepa (hawz Binna wa-Istabba $)^{56}$.

Sin entrar a valorar el contexto historiográfico, contamos con algunos datos de sumo interés en lo que concierne a Estepa:

1. El texto deja intuir que el río Genil era el límite del alfoz (hawz) de Estepa y de esa otra localidad llamada Peña (Binna), relacionadas entre sí $y$, con toda probabilidad, relativamente cercanas.

2. Precisamente, estamos en condiciones de proponer una identificación para esa Peña. Según la documentación de la orden de Santiago, uno de los límites de la Tierra de Estepa era la Sierra de Peña Rubia (Peña Ruvia), apelativo que ha de ser resultado de su condición de promontorio calizo. Entendíamos que esa sierra que delimitaba el alfoz de Estepa, según se anuncia en la documentación antes mencionada ${ }^{57}$, era la actual sierra de Peñarrubia. Así lo planteamos en su momento, siguiendo a Simonet ${ }^{58}$. Entre las entidades

55 Algunas valoraciones sobre este cargo en V. Martínez Enamorado, Al-Andalus desde la periferia, pp. 360-364, con referencias a Estepa.

56 Ibn al-Qūtịya, Ta'rīj iftitāh hp. 110; trad. castellana, p. 94.

57 "Ansy mesmo, en honze días del mes de otubre, se bio desde la dicha dehesa de la Roda y la dehesa de Gilena, van començando desde el Hojo del Toro que dizen, y yendo por el camino Real de Málaga que va a Estepa, hasta dar en la Sierra de Algaydilla, e llegar a Peña Ruvia, volver por el camino que ba de Estepa a Alameda"; "e comienza la dicha sierra desde el camino que ba de Estepa a Gilena la Alta a la mano yzquierda, e entra elne/sta sierra la sierra de los Cabrones, que es asomando a Alamedilla, e toda la sierra de las Algaydillas hasta la punta de Peña Ruvia, que es hasta el camino que va de Estepa a Antequera que va por la Venta del Alcaide "; R. Garza Cortés, Villa de Estepa, pp. 130 y 145, respectivamente.

58 Según F.J. Simonet Baca, Glosario II, p. 433, se trata de "Peñarrubia", idea que hemos mantenido en diversas contribuciones; por ejemplo, V. Martínez Enamorado, El Medievo, pp. 211-300; V. Martínez Enamorado, Al-Andalus desde la periferia, p. 286. 
de Bobastro y Teba, a escasísimos kilómetros de una y de otra, existe en los alrededores de este accidente orográfico un poblamiento andalusí destacado, seguramente del tipo alquería (bajo la desaparecida localidad de Peñarrubia, engullida en los años 70 de la pasada centuria por el embalse de Guadalteba), donde en fechas tempranas se instalarán árabes lajmíes, pues Ibn Hazm dice que de Ayyūb ibn Habīb al-Lajmī queda descendencia [en el siglo X] en las inmediaciones de Peña de la cora de Rayya (bi-ŷānib Binna min kūrat Rayya) ${ }^{59}$.

Sin embargo, nos informa el arqueólogo de Estepa, José María Juárez, que esa Peñarrubia a la que se refiere la documentación castellana no es otra sino una peña muy bien identificada, cerca de Lora de Estepa, que conserva el nombre y que cumple con todas las garantías geográficas y toponímicas que propone el itinerario seguido por los visitadores: sierra de la Algaidilla, el camino real de Málaga a Estepa, la Alamedilla y que es hasta el camino que va de Estepa a Antequera. Los dos promontorios llamados de la misma manera muy posiblemente estaban en Rayya y no resulta fácil proponer una adscripción a una de ellas como emplazamiento en el que se implantó Ayyūb ibn Ḥabīb al-Lajmī.

La fortaleza de Estepa comenzará a adquirir ciertas funciones protourbanas a partir del siglo X, muy posiblemente tras el fin de la revuelta hafșūní. La estabilización política que supone el Califato trae consigo la creación de una red de entidades poblacionales que asumen ciertas funciones urbanas, sin desarrollar en plenitud, con todo, las propias de una ciudad de tamaño medio. El sur de Córdoba y el sur-este de Sevilla -en general todo el valle del Guadalquivir-, están repletos de casos que pueden asimilarse a Estepa: pequeñas mudun, evolucionadas desde alquerías más o menos fortificadas en época emiral que rigen alfoces campesinos plagados de alquerías aún más reducidas y sin elementos poliorcéticos de entidad. Los ejemplos son prolijos: Baena, Osuna, Écija, Cabra, Priego de Córdoba, Lucena y algunas más. La locución empleada en algunos ejemplos por al-Idrīsī para definir esta realidad, $\mathrm{ka}$ l-madìna (= "como una ciudad"), no puede ser más expresiva. Estepa, aún faltando la referencia explícita idrisiana, se aviene bien a ese concepto de "casi ciudad" o "como una ciudad" ${ }^{\circ}$. Si el gran geógrafo ceutí no destina a Estepa referencia alguna en su Nuzha, en su otra obra, Uns al-muhay $\hat{y}^{61}$, la incluye simplemente

59 Ibn al-Qūtiyya, Iftitāh, p. 110; trad. castellana, p. 94. Este personaje era sobrino de Mūsà ibn Nuṣayr, instalado allí desde el siglo VIII; sobre el personaje, M. Fierro, Familias, núm. 6.

60 Se emplea para otras localidades distintas a Estepa, como Bezmiliana; $c f r$. C. MazzoliGuintard, Quelques éléments.

${ }^{61}$ Al-Idrīsī, Uns al-muhaŷ, f. 150, p. 56; trad. castellana, p. 87; estudio de J. Abid Mizal, p. 238 , núm. 307. 
como fortaleza (hișn Istabba) separada de Osuna ocho millas, en las distancias establecidas entre Córdoba y distintas localidades.

Con anterioridad, su función de enlace estratégico entre el eje EsteOeste (Ilbira-Sevilla) y Norte-Sur (Rayya-Córdoba), se pone de manifiesto a partir del interés que manifiestan los 'abbādíes de Sevilla y los ziries de Granada por ejercer un dominio efectivo sobre este lugar. En las llamadas "Memorias de "Abd Allāh", el emir granadino nos informa de la ocupación de la fortaleza, calificada de "gran refugio" (ma' qil 'ażìm) ${ }^{62}$, por parte del qā'id del zìrí, mencionado únicamente con su ism, Kabbāb, cuando después será nombrado con un breve nasab, Ibn Tamit. No hay dudas en considerar a uno y a otro el mismo personaje. Al parecer se trata de uno de esos individuos -un beréber, según la onomástica- que, actuando en principio con ciertos visos de legitimidad al estar nombrado por un gobernante, optará por realizar una política de bandidaje al margen de cualquier autoridad. 'Abd Allāh aporta una semblanza de él nada halagüeña, pero lo que nos importa en este momento es destacar el ejercicio del gobierno por delegación (era su alcaide) sobre dos plazas destacadas que el zìrí dominaba el norte de la extinta Rayya, Antequera y Archidona ${ }^{63}$. Tal vez se encuentre explicación en esa anterior vinculación la ocupación por parte de este Kabbāb de la fortaleza de Estepa, cercana a la región de Sevilla (nāhiya Išbiliyya), pero no en Sevilla, como el granadino anuncia:

\begin{abstract}
Aún insistió Ibn 'Ammār en pedirle que firmáramos un pacto al que habríamos de atenernos, y le inclinó a que me cogiera Estepa (Istabba), importante castillo (ma'qil 'azìm) próximo a la región de Sevilla ( $\hat{y}$ ihăt Išbilliyya) y del que mi alcaide Kabbāb se había apoderado durante las hostilidades. En vista de eso yo le pregunté que se iba a hacer con Alcalá, y al cabo nos pusimos de acuerdo en trocar Qal'at Aštalir/Alcalá la Real por Estepa ${ }^{64}$.
\end{abstract}

La mayor cercanía a Granada de Alcalá la Real impone el truque de una plaza por otra: el 'abbādí se queda con Estepa y Alcalá la Real pasa a manos del zīrí. La impresión que se obtiene de este tejemaneje del intercambio de plazas demuestra la precariedad política del sistema de taifas, lo que no significa, muy al contrario, atonía urbana. De hecho, entendemos que será en esa centuria (XI) cuando Estepa evolucione claramente hacia una acumulación de actividades urbanas que la conviertan en madīna.

62 Lo que Emilio García Gómez y Evariste Lévi-Provençal traducen de manera un tanto libre por importante castillo.

63 Abd Allāh ibn Buluqqīn, al-Tibyān, pp. 114 y 117-170; trad. castellana, pp. 185 y 189-195.

64 Ibidem, p. 102; trad. castellana, p.161. 
En efecto, la consideración de madīna que le otorga al-Himyari ${ }^{-65}$ viene a significar de alguna manera que el proceso evolutivo se cierra: de alquería fortificada ${ }^{66}$, concepto que se presenta bajo el término genérico de hiṣn, hasta ciudad, pasando antes por la categoría de ma'qil 'azìm, este último término escondiendo muy posiblemente esa condición de madina que sin duda la había obtenido con anterioridad (segunda mitad del siglo X o inicios del XI) por la acumulación de funciones de carácter urbano o proto-urbano. Entre ellas, las propias de una entidad de población con cargos religiosos relativamente autónomos, como el de "director de la oración" (șạhib al-ṣalāt) o alfaquí (alfaqih), ambos constatados en un personaje de cronología tan temprana como 'Uțmān ibn Sa'īd ibn al-Bašir ibn Gālib ibn Fayḍ al-Lajmī, fallecido en Estepa en 373/983-984 y que fue alfaquí de su ciudad y director de la oración en su mezquita aljama $^{67}$. Su extraña vinculación con Sidonia no sólo la recoge alḤimyarī, sino que también se hace eco de ella Ibn al-Faraḍī, pues a este'Uțmān ibn Sa ‘̄id al-Lajmī lo incluye entre la gente de Sidonia (min ahl Šidūuna) ${ }^{68}$.

Antes de su incorporación a la Corona de Castilla, Estepa dará otro ilustre ulema, de nombre Abū Isḥāq Ibrāhīm ibn 'Alī ibn Ibrāhīm ibn Muḥammad ibn 'Abd Allāh ibn Aglab al-Jawlānī al-Zawwālī, de la gente de Estepa (min ahl Istabba $)^{69}$, sobre el que Rafael Valencia ha dado sus coordenadas biográficas y, por tanto, no insistiremos. Sólo queremos decir que su sola comparecencia en los repertorios biográficos viene a apoyar esa noción de Estepa como centro urbano, idea que se anuncia, aunque sea de manera indirecta, por la expresión ahl Isțabba, "gentes de Estepa" entre los que se situaban en posición de privilegio sus ulemas. Sólo algunos de ellos pudieron sobresalir, pero su sola presencia demuestra la categoría urbana (o casi urbana) del enclave por esas fechas.

Sin embargo, en el periplo del año 571/1175 que realizó Ibn Mugāwir (nacido en 502/1108-1109 y fallecido en 587/1191) desde Sevilla hasta Denia, recogido en una epístola que estudiaran M. Bencherifa ${ }^{70}, \mathrm{M}^{\mathrm{a}} \mathrm{J}$. Rubiera Mata $^{71}$ y el que escribe ${ }^{72}$, Estepa no comparece en el trayecto entre Osuna y la

65 Al-Himyarī, Rawd al-mi'tārr, p. 23; trad. francesa, p. 23, núm. 18: "Ciudad (madīna) de al-Andalus, a 25 millas de Calsena (Qalsāna). De Calsena, que es la sede de Sidonia (qa'idat Šidūna) a Córdoba, hay cuatro días de marcha, correspondiéndose a una distancia de 110 millas".

66 Carecemos de la referencia precisa de alquería aplicada a Estepa.

67 Ibn al-Faradīi, Ta'rỉj al- 'Ulamā', p. 351, núm. 907. La noticia analizada en R. Valencia Rodríguez, Noticia de la Estepa árabe, p. 188.

68 Una interpretación a dicha noticia en V. Martínez Enamorado, Un país, p. 390, nota 46.

69 Al-Ru'aynī, Barnāmầ, p. 108, núm. 40.

70 M. Bencherifa, Ibn Mugāwir, pp. 1994, 62-63.

$71 \quad M^{\mathrm{a} J}$. Rubiera Mata, La tribu bereber.

72 V. Martínez Enamorado, Algunos topónimos andalusíes. 
Peña de los Enamorados (Șajrat al- 'Ǔ̌ša $\bar{q}$ ), aunque forzosamente hubiera de pasar por ese alfoz, dependencias a las que sí podía pertenecer dos topónimos mencionados en ese itinerario intermedio, después de Osuna y antes de la Peña: Wādī l-Ṭin, Fâŷy al-Mașālib ${ }^{73}$.

\section{SOBRE LOS LÍMITES DEL ALFOZ DE ESTEPA. \\ El CASO DE LA MEZQUITA DEL CORTIJO DE LAS MEZQUITILlAS (TÉRMINO MUNICIPAL DE ANTEQUERA, MÁlAGA)}

En esa documentación santiaguista anteriormente analizada se perfilan con precisión los límites de la "tierra" de Estepa. No dudamos que esa delimitación está recuperando, muy posiblemente en su integridad, viejas divisiones del período andalusí. No vamos a entrar a explicar el amojonamiento del término de Estepa, pero si queremos llamar la atención sobre uno de esos límites, el del Cortijo de las Mezquitas, en el término municipal de Anteque$\mathrm{ra}^{74}$, por reunir una serie de características que lo hacen muy peculiar.

En efecto, la mezquita, recientemente descubierta a pesar del topónimo y de la espectacularidad del edificio, se emplaza en un cruce de tierras, allí donde confluyen los viejos términos medievales de Antequera, Teba y Estepa, que se corresponden, respectivamente, con los actuales términos municipales de Antequera (en cuyo interior, por pocos metros, está), Campillos y Sierra de Yeguas. No es una casualidad esta ubicación: al construirse se buscó un emplazamiento estratégico, frente a Bobastro, y en la confluencia de varios alfoces y, estamos absolutamente persuadidos de ello, de varias circunscripciones territoriales o coras, al menos de dos de ellas. De su condición de límite entre territorios, hay cumplida referencia en distinta documentación castellana, como en estos tres testimonios extraídos de los amojonamientos realizados por la Encomienda santiaguista en las visitas de 1534 y 1544 :

Ese dicho día, continuando la dicha mojonera entre el término de Estepa e término e jurediçión de Teva, que es el thérmino de Campillos, jurediçion de Teva, e llegando a un hedifiçio antiguo, que se dize la mezquitilla, que parte término e es mojón entre Estepa e Antequera e Teva, yendo la dicha mojonera adelante ${ }^{75}$.

73 Las propuestas para la ubicación de estos lugares en Ibidem.

74 Sobre esa mezquita por ahora sólo contamos con el trabajo de C. Gozalbes Cravioto, El Cortijo "Las Mezquitas".

75 R. Garza Cortés, Villa de Estepa, p. 128, visita de 1533. 
E, ansy mesmo, desde la Aceña de Alhonoz, que es en el río Genil, que parte thérmino entre la dicha villa de Estepa e la çibdad de Heçija, hasta la Mezillitilla [sic], que parte término entre la dicha villa de Estepa e Antequera e Teva, ay otra çinco leguas, poco más o menos ${ }^{76}$.

Así mismo, pareze por la dicha visitación de término que la dicha villa de Estepa trae pleito con la çibdad de Antequera sobre un gran pedazo término tierras montes e algunas rasas que están de la otra parte de la mezquitilla, en el qual pedazo de monte tasaron los dichos alcalde e medidor que avía hasta cuatro mil hanegas de tierra ${ }^{77}$.

En el Libro de Repartimiento de Antequera las referencias que hallamos a un paraje llamado Las Mezquitillas no pertenecen a este emplazado a su Occidente, sino a otro al Este, cerca del arroyo Burriana, posiblemente a una alquería llamada Burriana (¿Bițra Riyyāna ${ }^{78}$, como su homónima en la costa marcando también alguno de los límites de Rayya?):

Otro pedaço de tierras entre el arroyo de Burriana e Las Mezquitillas aquella ladera baja, porque la alta por estar en debate no se midió, e obo en la baja que obo quatro yubadas cincuenta arançadas ${ }^{79}$.

Quedó que no se midió ni repartió la tierra de las Mezquitillas qu'está litijiossa en Benamegil ${ }^{80}$.

En documentación del Archivo Municipal de Antequera, en deslindes sucesivos de 1551 y 1552 , vuelve a comparecer el topónimo ${ }^{81}$ :

Desde las mezquitillas ques mojón común y de ay a la atalaya bermeja y de alli a la junta de los caminos que va el uno a Sevilla y el otro a Córdoba todavía su derecera adelante por las cumbres y lomas del madroño

Las mezquitillas ques mojón común... abiendo llegado al cortjo que llaman de las mezquitas ques el sitio que divide los tres términos de Antequera, Estepa y Campillos ${ }^{82}$.

76 Ibidem, p. 153, visita de 1544.

77 Ibidem, p. 170, visita de 1544.

78 Sobre esta cuestión, V. Martínez Enamorado, Y al-Dājil arribó a al-Andalus, pp. 199-200.

79 Repartimiento de Antequera, ed. Alijo Hidalgo, f. 105v.

80 Ibidem, f. $153 \mathrm{v}$.

81 Otras citas más tardías a finales del siglo XVI y durante los siglos XVII, XVIII y XIX en C. Gozalbes Cravioto, El Cortijo "Las Mezquitas", p. 14.

82 J.A. Rodríguez Martín, Pleitos entre Estepa y Antequera. 
Se comprueba esa condición estratégica de esa alquería con tan monumental mezquita, en el cruce de caminos que van a Sevilla y Córdoba desde Málaga y amojonando tres términos que pertenecieron a tres alfoces andalusíes de época omeya: el de Teba (Itạba/Atțība), sin duda formando parte de Tākurunnā, al oeste; el de Antequera (Antaqīra), al este, integrándose como distrito en Rayya; y el de Estepa (Istabba), posiblemente también en Rayya o formando una entidad propia por determinar. Aunque desarrollaremos estas hipótesis de una manera más prolija en otro trabajo que estamos ultimando, esta mezquita se edificó posiblemente en el siglo X no sólo como baluarte frente a Bobastro y la revuelta de Ibn Hafșūn, sino también con un sentido de delimitación de distritos y alfoces. Estepa, independientemente de que fuese cora o un iqlim de Rayya, contaba en el siglo X -cronología que atribuimos por sus rasgos formales a la mezquita- con su propia "jurisdicción fiscal", que es a la postre lo que significaba en al-Andalus un distrito, confinando con Tākurunnā y con otro iqlīm de Rayya, Antequera.

\section{APÉNDICE. REFERENCIAS HISTORIOGRÁFICAS DE LA ESTEPA ANDALUSÍ ${ }^{83}$}

\begin{tabular}{|c|c|c|c|c|}
\hline $\begin{array}{l}\text { AUTOR Y } \\
\text { OBRA }\end{array}$ & $\begin{array}{l}\text { CRONOLOGÍA DEL } \\
\text { ACONTECIMIENTO }\end{array}$ & $\begin{array}{l}\text { TOPÓNIMO } \\
\text { ESTEPA }\end{array}$ & $\begin{array}{l}\text { CARACTERIZACIÓN } \\
\text { TERMINOLÓGICA }\end{array}$ & $\begin{array}{l}\text { LUGARES VIN- } \\
\text { CULADOS }\end{array}$ \\
\hline $\begin{array}{l}\text { Ibn al-Qūtityya } \\
\text { Ta'rij Iftitāhh }\end{array}$ & $\begin{array}{l}\text { Último tercio del siglo IX } \\
\text { (revuelta de Ibn Hafșūn) }\end{array}$ & استبة & Hawz & $\begin{array}{l}\text { Binna (¿Peñarru- } \\
\text { bia?) }\end{array}$ \\
\hline $\begin{array}{l}\text { Ibn Hayyān } \\
\text { Muqtabis III }\end{array}$ & $\begin{array}{l}\text { Toma por parte de Ibn Haf- } \\
\text { sūn de la fortaleza de Es- } \\
\text { tepa, de donde se desaloja } \\
\text { al representante del sultán } \\
\text { ('āmil al-sulțān) en } 276 / 889\end{array}$ & اصطبة & Hiṣn & $\begin{array}{l}\text { Tākurunnāa, Écija y } \\
\text { Osuna }\end{array}$ \\
\hline $\begin{array}{l}\text { Ibn al-Jatịib, } \\
\text { A'māl }\end{array}$ & & اسطبة & & Écija \\
\hline $\begin{array}{l}\text { Al-Bunnāhī, } \\
\text { Marqaba }\end{array}$ & $\begin{array}{l}\text { Se definen los límites de la } \\
\text { cora de Rayya, posiblemente } \\
\text { del siglo X }\end{array}$ & استبة & Hawz & $\begin{array}{l}\text { Río Genil, Bename- } \\
\text { jí, Gilena, Castillo } \\
\text { de Anzur, Aljonoz } \\
\text { (límites de Rayya) }\end{array}$ \\
\hline
\end{tabular}

83 Las referencias se ordenan de acuerdo con la cronología del acontecimiento en cuestión. Si es una descripción corográfica del enclave en la que el autor describe la realidad coetánea a su tiempo, como la de al-Idrīsì, se aporta la cronología del geógrafo. Cuando creemos que se trata de recreaciones a posteriori ( $\underline{i} i k r$, al-Himyarī, al-Bunnāhī) se incluye la fecha de la que se entiende es la cronología de la realidad urbana reelaborada. 


\begin{tabular}{|c|c|c|c|c|}
\hline $\begin{array}{l}\text { Ibn al-Faradīi, } \\
\text { Ta'rij al- } \\
\text { 'Ulamā' }\end{array}$ & $\begin{array}{l}\text { Biografía de 'Utmān ibn } \\
\text { Sa'īid ibn al-Bašir ibn Gālib } \\
\text { ibn Fayḍ al-Lajmī (fallecido } \\
\text { en Estepa en 373) }\end{array}$ & استبة & & Sidonia \\
\hline $\begin{array}{l}\text { Dikr bilād al- } \\
\text { Andalus }\end{array}$ & $\begin{array}{l}\text { Descripción de los castillos } \\
(\text { hușūn y ciudades (mu- } \\
\text { dun) de las dependencias de } \\
\text { Rayya, "que es Málaga", po- } \\
\text { siblemente del siglo X }\end{array}$ & اصطبة & Hișn/madina & $\begin{array}{l}\text { Marbella, Fuengirola, } \\
\text { Cártama, Comares, } \\
\text { Vélez-Málaga, Coín, } \\
\text { Alhama, y Antequera } \\
\text { ("ciudades" y "castil- } \\
\text { los" de Rayya) }\end{array}$ \\
\hline $\begin{array}{l}\text { 'Abd Allāh, } \\
\text { Tibyānn }\end{array}$ & $\begin{array}{l}\text { En el enfrentamiento entre los } \\
\text { 'abbādíes y los ziríes, Estepa } \\
\text { representa una posición estra- } \\
\text { tégica en poder de estos últi- } \\
\text { mos que la intercambian con } \\
\text { aquellos por Alcalá la Real } \\
\text { (segunda mitad del siglo XI) }\end{array}$ & اسطبة & Ma'qul 'ażim & Alcalá la Real \\
\hline 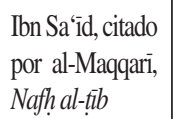 & $\begin{array}{l}\text { Mención de una obra poé- } \\
\text { tica en la que se califica a } \\
\text { Estepa de cora (siglo XII) }\end{array}$ & استبة & Kūra & \\
\hline $\begin{array}{l}\text { Al-Himyarī, } \\
\text { Rawd al- } \\
\text { mi'țâr }\end{array}$ & $\begin{array}{l}\text { Entrada "Estepa" en esta } \\
\text { gran enciclopedia geográfica, } \\
\text { del siglo XIV, aunque po- } \\
\text { siblemente esté refiriéndose } \\
\text { al lugar en los siglos XI o XII. }\end{array}$ & اصطبة & Madina & Calcena y Sidonia \\
\hline $\begin{array}{l}\text { Al-Idrīisi, Uns } \\
\text { al-muhaŷy }\end{array}$ & $\begin{array}{l}\text { Se menciona a Estepa, sepa- } \\
\text { rada ocho millas de Osuna } \\
\text { (siglo XII) }\end{array}$ & استبة & Hịṣn & Osuna \\
\hline $\begin{array}{l}\text { Al-Maqqarī } \\
\text { Nafh al-țib }\end{array}$ & $\begin{array}{l}\text { Se citan las dependencias } \\
\text { de Córdoba, entre las que se } \\
\text { encuentra Estepa, posible- } \\
\text { mente en siglo XII }\end{array}$ & اسطبة & A'māl Qurțuba & $\begin{array}{l}\text { Écija, Porcuna, Cabra, } \\
\text { Ronda, Belalcázar, } \\
\text { Almodóvar, Estepa, } \\
\text { Baena, Lucena y otros }\end{array}$ \\
\hline $\begin{array}{lr}\text { Ibn } & \text { 'Abd } \\
\text { al-Mālik } & \text { al- } \\
\text { Marrā ku ší } \\
\text { Dayl }\end{array}$ & $\begin{array}{l}\text { Biografía de 'Alī ibn 'Alī } \\
\text { ibn Aḥmad ibn Sulaymān } \\
\text { al-Nafzì, estepeño (Istabīi), } \\
\text { fallecido en Marraquech en } \\
\text { 613/1216-1217 }\end{array}$ & اسطبة & & Granada \\
\hline $\begin{array}{l}\text { Al-Ru'aynī, } \\
\text { Barnāmây }\end{array}$ & $\begin{array}{l}\text { Biografía de Abū Ishāāq Ibra- } \\
\text { hīm ibn 'Alīi ibn Ibrāhīm ibn } \\
\text { Muhammad ibn 'Abd Allāh } \\
\text { ibn Aglab al-Jawlānī al-Za- } \\
\text { wwālì, de la gente de Estepa } \\
\text { (min ahl Istabba) }\end{array}$ & اسطبة & $\ldots$ & $\ldots$ \\
\hline
\end{tabular}




\section{BIBLIOGRAFÍA CITADA}

\section{FUENTES ÁRABES Y CASTELLANAS}

'Abd Allāh ibn Buluqqīn, Kitāb al-Tibyān li-l-amīr 'Abd Allāh ibn Buluqqìn, ajar umarā' banī Zīrì bi-Garnāța, ed. completa del texto árabe por A. T. Tịibī, Rabat, 1995; trad. española, El siglo XI en $1^{a}$ persona. Las 'Memorias' de 'Abd Allāh, último rey zìrí de Granada destronado por los almorávides (1090), de E. Lévi-Provençal, E. García Gómez, con introducción y notas, Madrid, Alianza, 1980.

Alfonso XI, Libro de la Montería, estudio y ed. crítica por $\mathrm{M}^{\mathrm{a}}$ I. Montoya Ramírez, Granada, Universidad de Granada, 1992.

Al-Bunnāhī, Kitāb al-Marqaba al- 'ulyà fi man yastahiqq al-qaḍà wa-l-futyà, ed. E. Lévi-Provençal, El Cairo, 1948.

Crónica Anónima de 'Abd al-Raḥmān III al-Nāṣir, ed. y trad. por E. LéviProvençal, E. García Gómez, Madrid-Granada, CSIC, 1950.

Dikr bilād al-Andalus, ed. y trad. de L. Molina, Una descripción anónima de al-Andalus, 2 vols., Madrid, CSIC, 1983.

Al-Himyarī, Kitāb al-rawd al-mi 'țār fì ajbār al-aqtār, ed. y trad. francesa de E. Lévi-Provençal, La Péninsule Ibérique au Moyen Age d'après le 'Kitāb al-rawd al-mi 'țār fi ajbār al-aqtāar' d'Ibn 'Abd al-Mun 'im alHimyarī, Leiden, 1938.

Ibn 'Abd al-Malik al-Marrākuš̄i, al-Da ayl wa-l-Takmila li-kitābay almawșūl wa l-șila, vol. I (2 partes), ed. M. ben Šarífa, Beirut, 1971; vols. IV (final), V (2 partes) y VI (2 partes), ed. I. 'Abbās, Beirut, 1964, 1965 y 1973, respectivamente; vol. VIII (2 partes), ed. M. ben Šarifa, Rabat, 1984.

Ibn 'Āṣim, Ŷannat/Ŷunnat al-Riḍa fi l-taslīm li-ma qaddara Allāh wa-qaḍa, ed. Șalāh Ŷarrār, 3 vols., Ammán, 1989.

Ibn al-Faraḍi, Ta'rìj 'ulamā'al-Andalus wa-l-ruwāt li-l- 'ilm bi-l-Andalus, ed. Ibrāhīm al-Abyārī, Beirut-El Cairo, 3 y 4, 1989.

Ibn Hayyān, al-Muqtabis. Tome Troisième. Chronique du Règne du Calife Umaiyade 'Abd Allāh à Cordoue. Texte arabe publié pour la première fois d'après le manuscrit de la Bodléienne avec une introduction, ed. P. Melchor M. Antuña, París, 1937.

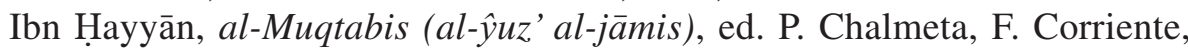
M. Șubh, Madrid, 1979; trad. castellana, Ma J. Viguera, F. Corriente, Crónica del califa 'Abderrahmān an-Nāṣir entre los años 912 y 942 (al-Muqtabis V), Zaragoza, Anubar, 1982.

Ibn 'Idārī, al-Bayān al-Mugrib fi ajbār al-Andalus wa-l-Magrib, vol. I y II, ed. E. Lévi-Provençal, G. S. Colin, Histoire de l'Afrique du Nord et de 
l'Espagne musulmane intitulée Kitāb al-Bayān al-Mughrib par Ibn 'Idhārī al-Marrākushī et fragments de la chronique de 'Arīb, nouvelle édition publiée d'après l'édition de 1848-1851 de R. Dozy et de nouveaux manuscrits, París, 1948-1951; trad. francesa de E. Fagnan, Histoire de l'Afrique et de l'Espagne intitulée al-Bayano al-Mogrib, 2 vols., Argel, 1901-1904; III, ed. G.S. Colin, E. Lévi-Provençal, alBayān al-Mugrib, tome troisième. Histoire de l'Espagne musulmane au Xème siècle. Texte arabe publié pour la première fois d'après un manuscrit de Fès, París, 1930; trad. española F. Maíllo Salgado, La caída del califato de Córdoba y los Reyes de Taifas (al-Bayān alMugrib), est., trad. y notas, Salamanca, Universidad de Salamanca, 1993; Crónica Anónima de los Reyes de Taifas, trad. española parcial por F. Maíllo Salgado del vol. III del Bayān, Madrid, Akal Universitaria, 1991.

Ibn al-Jațīb, al-Ihāta fi ajbār Garnāta, ed. Muhammad 'Abd Allāh 'Inān, 4 vols., El Cairo, 1973-1977 (I: 1973, II: 1974, III: 1975, IV: 1977). V: Nuṣūs ŷadīd (textos nuevos inéditos), 'A. S. Šaqūr, Tetuán, 1988.

Ibn al-Jațīb, Lamhat al-badriyya fi l-dawla al-nașariyya, ed. Muhibb al-Dīn al-Jatiīb, 1980, $3^{\mathrm{a}}$ ed., trad. española e introducción de J. $\mathbf{M}^{\mathrm{a}}$ Casciaro Ramírez, con estudio preliminar de E. Molina López, Historia de los Reyes de la Alhambra, Granada, Universidad de Granada, 1998.

Ibn al-Jațīb, Kitāb A'māl al-a 'lām fì man būyi'a qabl al-ihtilām min mulūk al-Islām, ed. E. Lévi-Provençal, con introd. y notas, Histoire de l'Espagne musulmane, Rabat, 1934, reed. Beirut, 1956.

Ibn al-Qūtiyya, Ta'rīj iftitāh al-Andalus, ed. y trad. de J. Ribera, Historia de la conquista de España de Abenalcotía el Cordobés, Madrid, 1926.

Ibn Sa'īd al-Magribī, al-Mugrib fi hulà al-Magrib, ed. Šawqī Dayf, 2 vols., El Cairo, 1953.

Al-Idrīsī, Nuzhat al-muštāq, ed. y trad. francesas parciales de R. Dozy, M. J. de Goeje, Description de l'Afrique et de l'Espagne, Leiden, 1968, reimpresión de la ed. de 1886; trad. española de la parte relativa a al-Andalus por A. Vázquez, Descripción de España de Abu-Abd-AllMohamed-al-Edrisí, Madrid, 1901, reeditada en A. Ubieto Arteta, Geografía de España, Valencia, 1974; trad. francesa de P. A. Jaubert, Idrîsî. La première géographie de l'Occident, con presentación, notas, índices, cronología y bibliografía de H. Bresc, Nef, París, GF Flammarion, 1999.

Al-Idrīsī, Los caminos de al-Andalus en el siglo XII según Uns al-muhaŷ waRawd al-furaŷy (Solaz de corazones y prados de contemplación), pró$\operatorname{logo}$ de $\mathrm{M}^{\mathrm{a}} \mathrm{J}$. Viguera Molins, estudio, ed., trad. y anotaciones de Jassim Abid Mizal, Madrid, CSIC, 1989. 
Al-Maqqarī, Nafh al-țìb min guṣn al-Andalus wa l-rațīb, ed. I. 'Abbās, 8 vols., Beirut, 1968.

Repartimiento de Antequera, ed. de F. Alijo Hidalgo, Antequera y su Tierra. 1410-1510. Libro de Repartimientos, Málaga, Arguval, 1983.

Al-Ru'aynāī, Barnāmây šuyūj al-Ru'aynī, ed. Ibrāhīm Šuyūj, Damasco, $1381 / 1962$.

Yāqūt al-Ḥamawī, Mu'ŷam al-buldān, ed. Wüstenfeld, 6 vols, Leipzig, 18661873; trad. española de los textos referentes a al-Andalus de Gamal 'Abd al-Karìm, La España musulmana en la obra de Yāqūt (s. XIIXIII). Repertorio enciclopédico de ciudades, castillos y lugares de al-Andalus extraído del Mu 'ŷam al-buldān (Diccionario de países), "Cuadernos de Historia del Islam" 6 (1974).

\section{ESTUDIOS MODERNOS}

Acién Almansa, Manuel, La formación y destrucción de al-Andalus, en Barceló, M. (dir.), Historia de los pueblos de España. Tierras Fronterizas (I). Andalucía. Canarias, Barcelona, Argos Vergara, 1984, pp. 243-267.

Arjona Castro, Antonio, Andalucía musulmana. Estructura político-administrativa, Córdoba, Diputación de Córdoba, 1980.

Barceló, Miquel, Notes berbers i saharianes entorn del Sharq al-Andalus, en Barceló, M. (ed.), Sobre Mayūrqa, Palma de Mallorca, Museu de Mallorca, 1984, pp. 133-141.

Bencherifa, Muḥammad, Ibn Mugāwir al-Šātibī hayatu-hu wa-ātāru-hu, Casablanca, 1994.

Calero Secall, $\mathrm{M}^{\mathrm{a}}$ Isabel; Martínez Enamorado, Virgilio, Málaga, ciudad de al-Andalus, Málaga, Universidad - Ágora, 1995.

Fierro, Maribel, Familias del Ta'rīj Iftitāh de Ibn al-Qūtiyya en Estudios Onomásticos y Bibliográficos de al-Andalus, IV, Granada, CSIC, 1990, pp. 41-70.

Garza Cortés, Rosario, La villa de Estepa al final del dominio santiaguista, Estepa, Ayuntamiento de Estepa, 1996.

Gozalbes Cravioto, Carlos, El Cortijo "Las Mezquitas". Una mezquita medieval en la Vega de Antequera, Antequera, [s.n.], 2006.

Guichard, Pierre, Al-Andalus. Estructura antropológica de una sociedad islámica en Occidente, Barcelona, Barral, 1976.

Juárez Martín, José María, Prospección arqueológica superficial del término municipal de Estepa (Sevilla), en Anuario Arqueológico de Andalucía/1988, vol. III: Actividades de urgencia, Sevilla, Consejería de Cultura de la Junta de Andalucía, 1990, pp. 340-343. 
López Ontiveros, Antonio; Valle Buenestado, Bartolomé; García Verdugo, Francisco R., Caza y paisaje geográfico en las tierras béticas según el Libro de la Montería en Andalucía entre Oriente y Occidente (1236-1492), Actas del V Coloquio Internacional de Historia Medieval de Andalucía, Córdoba, Diputación Provincial de Córdoba, 1988, pp. 281-307.

Martínez Enamorado Virgilio, El Medievo. Entre dos sistemas: islamización y castellanización, en García Alfonso, Eduardo; Martínez Enamorado, Virgilio; Morgado Rodríguez, Antonio, El Bajo Guadalteba (Málaga): espacio y poblamiento. Una aproximación arqueológica a Teba y su entorno, Málaga, Diputación de Málaga, 1995, pp. 211-300.

Martínez Enamorado, Virgilio, Al-Andalus desde la periferia. La formación de una sociedad musulmana en tierras malagueñas (siglos VIII-X), Málaga, Diputación Provincial de Málaga, 2003.

Martínez Enamorado, Virgilio, Algunos topónimos andalusíes de la Tierra de Antequera, "Estudios sobre Patrimonio, Cultura y Ciencias Medievales" 7-8 (2006), pp. 219-241.

Martínez Enamorado, Virgilio, Reflexiones sobre el estudio de al-Andalus como sociedad o, de nuevo, qué arqueología para al-Andalus, en García Sanjuán, A. (ed.), Saber y sociedad en al-Andalus. IV-V Jornadas de Cultura Islámica en Almonaster la Real (Huelva), Huelva, 2006, pp. 193-237.

Martínez Enamorado, Virgilio, Y al-Dājil arribó a al-Andalus... En torno al desembarco de 'Abd al-Rahmān I en la playa de Burriana/Bitruh Riyyāna, "Al-Qanțara” 27 (2006), pp. 199-200.

Martínez Enamorado, Virgilio, Un país 'que reporta todo tipo de bienes'. Sobre el sentido histórico de la cora de Sidonia, "Revista Atlántica-Mediterránea de Prehistoria y Arqueología Social" 10 (2008), pp. 375-398.

Mazzoli-Guintard, Christine, Quelques éléments du signifié de madīna: l'emploi de 'ka' chez al-Idrìsī, "Sharq al-Andalus" 9 (1992), pp. 187-195.

Mendoza Garrido, Juan Miguel, Notas sobre la propiedad de la tierra en Estepa a fines de la Edad Media. La hacienda de Juan Jiménez Cavallero, en Actas de las Primeras Jornadas de Historia de Estepa (marzo, 1994), Estepa, Ayuntamiento de Estepa, 1995, pp. 207-222.

Navarro de la Torre, Luisa, Algunos apuntes sobre el problema de la tierra en Estepa entre el fin de la frontera y los inicios de la Modernidad, en Actas de las Primeras Jornadas de Historia de Estepa (marzo, 1994), Estepa, Ayuntamiento de Estepa, 1995, pp. 193-206.

Oliver Pérez, $\mathrm{M}^{\mathrm{a}}$ Dolores, El arabismo Alcoba y los topónimos Alcoba, Alcobillas, Cuba y Cubillas, "Anuario de Lingüística Hispánica" 9 (1993), pp. 165-194. 
Pabón y Suárez de Urbina, José Manuel, Sobre los nombres de la 'villa' romana en Andalucía en Estudios dedicados a R. Menéndez Pidal, IV, Madrid, [s.n.],1953, pp. 87-165.

Peinado Santaella, Rafael Gerardo. Estepa en la Edad Media (711-1559) en Actas de las Primeras Jornadas de Historia de Estepa (marzo, 1994), Estepa, Ayuntamiento de Estepa, 1995, pp. 149-181.

Prieto Pérez, Joaquín Octavio, El Marquesado de Estepa. 1751. Según las Respuestas Generales del Catastro de Ensenada, Madrid, Centro de Gestión Catastral y Cooperación Tributaria - Tabapress, 1996.

Rodríguez Martín, J.A., Pleitos entre Estepa y Antequera en el siglo XVI: el caso de Alameda en Actas I Jornadas de Historia de Estepa, Sevilla, [s.n.], 1995, pp. 287-296.

Rubiera Mata, $\mathrm{M}^{\mathrm{a}}$ Jesús, La tribu beréber de los Gazules en la toponimia hispánica, "Al-Andalus-Magreb", 6 (1998), pp. 11-16.

Simonet Baca, Francisco Javier, Glosario de voces ibéricas y latinas usadas entre los mozárabes, 2 vols, Madrid, Atlas (facsímil), 1888.

Tahiri, Ahmed, Agricultura y poblamiento rural en Sevilla durante la época 'abbādí, Sevilla, Ayuntamiento de Sevilla, 2001.

Terés Sádaba, Elías, Materiales para el estudio del toponimia hispanoárabe. Nómina fluvial. Tomo I, Madrid, CSIC, 1986.

Valencia Rodríguez, Rafael, Los territorios de la cora de Écija en época árabe en Actas del I Congreso sobre Historia de Écija, vol. I, Écija, Ayuntamiento de Écija, 1988, pp. 315-335.

Valencia Rodríguez, Rafael, Noticia de la Estepa árabe (Acerca de dos personajes estepeños) en Actas de las Primeras Jornadas de Historia de Estepa (marzo, 1994), Estepa, Ayuntamiento de Estepa, 1995, pp. 187-192.

Vallvé Bermejo, Joaquín, La división territorial de la España musulmana, Madrid, CSIC, 1986.

Vargas Jiménez, Juan Manuel; Romo Salas, Ana Salud; García Ramírez, $\mathrm{M}^{\mathrm{a}}$ Isabel, Aproximación a los modelos de asentamiento en el ámbito sureste de la Cora de Écija en Actas del III Congreso "Écija en la Edad Media”, Écija, Ayuntamiento de Écija, 1993, pp. 13-40.

Fecha de recepción del artículo: febrero 2012

Fecha de aceptación y versión final: mayo 2012 